\title{
Rancang Bangun Sistem Informasi Akuntansi Berbasis Web (Studi Kasus : PT. Yuju Indonesia)
}

\author{
Sufajar Butsianto, S.Kom, M.Kom ${ }^{1}$, Eka Febriliani . S.Kom² \\ Universitas Pelita Bangsa, Jl. Inspeksi Kalimalang No.9, Cibatu, Kec. Cikarang Pusat, \\ Bekasi, Jawa Barat 17530 \\ ${ }^{1}$ sufajar@pelitabangsa.ac.id
}

\begin{abstract}
Abstrak - Dalam proses pengelolaan keuangan, PT. Yuju Indonesia sudah menggunakan software General Ledger, walaupun sudah menggunakan aplikasi tersebut, masih ada beberapa pekerjaan yang dilakukan secara konvensional, seperti merekap satu persatu transaksi masuk dan keluar, pembuatan invoice untuk dikirim ke customer serta pembuatan laporan rugi laba yang masih menggunakan Microsoft Excel. Hal itu dikatakan belum efekktif sehingga dapat mengakibatkan terjadinya kesalahan dalam meng-input data, pencarian data terlalu lama serta keterlambatan dalam pembuatan laporan keuangan dan data yang dihasilkan tidak akurat. Dengan adanya permasalahan yang terjadi, maka dibuat sebuah rancang bangun sistem informasi akuntansi berbasis web menggunakan metode waterfall dengan teknik pengumpulan data yaitu observasi, wawancara dan studi pustaka serta metode perancangan yang digunakan adalah Unified Modelling Language (UML) dan metode pengujian menggunakan blackbox testing. Sistem yang dibangun ini menyediakan fasilitas seperti entri jurnal, laporan penjualan dan pembelian, daftar dan buat invoice baru, jurnal umum, buku besar, neraca saldo, laporan laba rugi, neraca keuangan serta pengaturan hak akses yang dapat memudahkan kinerja pegawai dalam pengolahan data keuangan sehingga dapat memberikan informasi keuangan yang lebih sistematis. Hasil dari blackbox testing menyimpulkan bahwa fungsi yang diharapkan berhasil sesuai dengan yang diharapkan.
\end{abstract}

Kata kunci : Sistem Informasi Akuntansi, Laporan keuangan, waterfall, blackbox testing.

\section{Pendahuluan}

Akuntansi sangat dibutuhkan oleh perusahaan dimasa kini. Dalam proses transaksi penjualan dan pembelian, tentu ada barang dan uang yang terlibat. Di dalam perusahaan yang cukup besar dengan perputaran jual-beli yang mencapai puluhan, ratusan, bahkan ribuan per hari, tentu akan ada banyak risiko human error, dimana ada yang terselip, tercatat dua kali, perhitungan yang meleset dan pelanggan yang ternyata berhutang melebihi batas (karena hutang yang diberikan oleh perusahaan dianggap terlalu berisiko). Selain itu akuntansi dibutuhkan untuk mengetahui keuntungan dan kerugian dari sebuah perusahaan.

PT. Yuju Indonesia merupakan perusahaan yang bergerak dibidang plastic injection dan assembly dan semakin berkembang menjadi vendor dari perusahaan otomotif. Dalam sistem informasi akuntansi, perusahaan telah menerapkan sistem database dalam pengelolaan transaksi pembelian, penjualan maupun transaksi keuangan lainnya dengan menggunakan software General Ledger. Software tersebut berfungsi untuk melihat kumpulan mutasi per-akun, saldo awal, serta saldo akhir yang nantinya akan digunakan lagi untuk membuat jurnal penyesuaian sampai kepada laporan keuangan.

Walaupun sudah menggunakan software General Ledger, masih ada beberapa pekerjaan yang dilakukan secara konvensional, seperti merekap satu persatu transaksi masuk dan keluar, pembuatan invoice untuk dikirim ke customer serta pembuatan laporan rugi laba yang masih menggunakan Microsoft Excel dan untuk memposting jurnal ke buku besar diperlukan ketelitian dalam menghitung satu persatu nilai akun yang terdapat di jurnal dengan menambahkan atau mengurangi nilainya berdasarkan posisinya di debit atau kredit. Jika sudah ditemukan nilai akhirnya, barulah nilai saldo akhir yang diperoleh dimasukkan ke akun di buku besar, begitupun dengan akun-akun lainnya sehingga nilai aktiva dan pasiva seimbang.

Hal itu dikatakan belum efektif sehingga dapat mengakibatkan terjadinya kesalahan dalam meng-input data, pencarian data terlalu lama serta keterlambatan dalam pembuatan laporan keuangan dan data yang dihasilkan tidak akurat. Yang paling umum terjadi adalah ketidakseimbangan antara posisi aktiva dan pasiva di buku besar. Jika seperti ini kejadiannya, langkah selanjutnya dalam membuat laporan keuangan belum bisa dilakukan. Ini sering kali menyebabkan terjadi kesalahan pada account balance, yang membuat kinerja menjadi kurang efisien, karena setiap kali harus menelusuri lagi, mencari di mana letak kesalahan yang dibuat.

Adapun tujuan penelitian ini adalah untuk membangun dan menghasilkan sistem informasi akuntansi dan membantu mempercepat dan mempermudah tugas admin keuangan dalam mengolah laporan keuangan, sehingga didapatlah laporan yang berkualitas dan membantu meminimalisir kesalahan dalam pembuatan laporan keuangan. 


\section{Tinjauan Pustaka}

2.1 Pengertian Sistem Informasi Akuntansi

Sistem informasi akuntansi adalah sebuah sistem yang memproses data dan transaksi guna menghasilkan informasi yang bermanfaat untuk merencanakan, mengendalikan dan mengoperasikan bisnis [1].

\subsection{Pengertian Siklus Akuntansi}

Dalam akuntansi terdapat siklus akuntansi yang terdiri dari kegiatan-kegiatan yang berhubungan dengan suatu proses pengidentifikasian, pengukuran, pelaporan informasi ekonomi. Akuntansi adalah tahapan kegiatan yang terus-menerus dan kembali pada tahapan awal akan membentuk siklus [2]. Kegiatan-kegiatan dalam akuntansi tersebut dapat dinyatakan dalam bentuk diagram sebagai berikut:

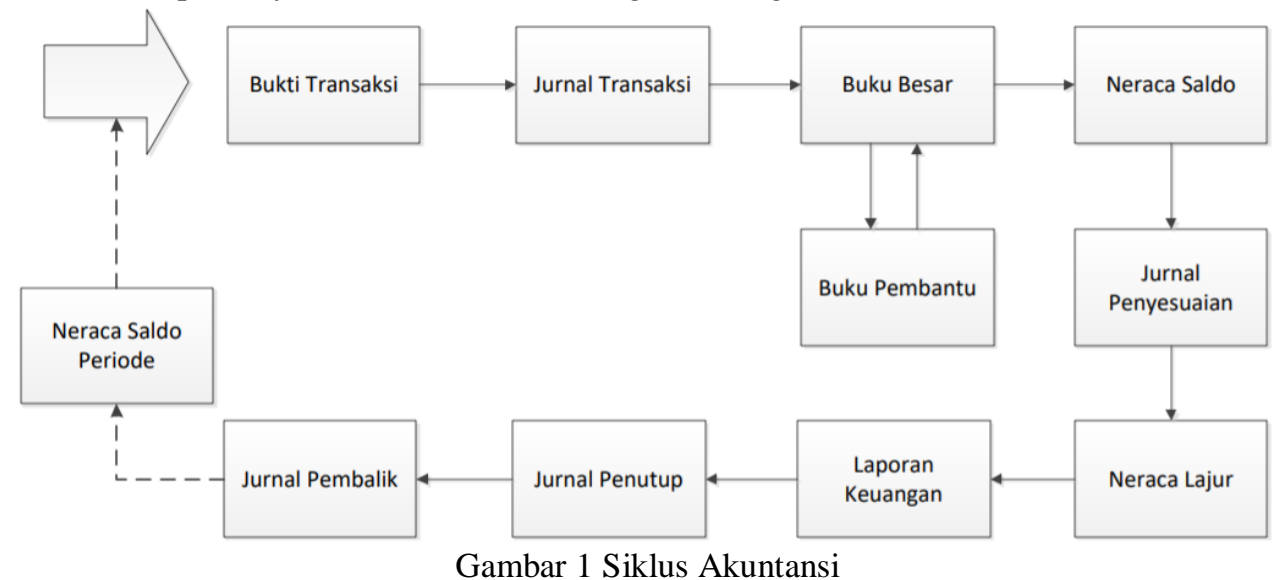

1. Bukti Transaksi

Bukti transaksi merupakan suatu dokumen yang menandai bahwa transaksi yang sah telah terjadi. Akuntansi hanya mencatat objek yang timbul akibat adanya transaksi yang sah dan dalam akuntansi tidak ada transaksi tanpa bukti transaksi, sehingga bukti transaksi ini merupakan unsur yang sangat penting [3].

2. Jurnal Transaksi

Jurnal atau sering disebut buku jurnal, merupakan buku catatan kronologis terhadap transaksi atau peristiwa keuangan di suatu perusahaan. Pencatatan kronologis berarti bahwa setiap transaksi dicatat sesuai dengan urutan tanggal transaksinya.

3. Buku Besar

Buku besar adalah suatu catatan akuntansi yang menggambarkan kenaikan atau penurunan aktiva atau utang (ekuitas) yang dibuat secara individu untuk setiap item laporan keuangan. Setiap rekening (akun) akan menjadi buku besar [4].

4. Neraca Saldo

Neraca saldo adalah suatu laporan yang memuat daftar akun beserta saldo-saldo baik itu akun yang bersaldo debet maupun bersaldo kredit [5].

5. Jurnal Penyesuaian

Jurnal penyesuaian adalah tempat pencatatan data-data transaksi tertentu pada akhir periode demi menyesuaikan jumlah rupiah yang terdapat dalam tiap akun terhadap kenyataan pada akhir periode tersebut [6].

6. Neraca Lajur

Neraca lajur sering disebut dengan kertas kerja (worksheet) dan berupa lembaran kertas berkolomkolom yang berisi semua urusan-urusan akun, baik akun riil maupun akun nominal, yang akan dijadikan dasar dalam penyusunan laporan keuangan [7].

7. Laporan Keuangan

Laporan keuangan merupakan media komunikasi pertanggungjawaban antara perusahaan dan pemiliknya atau pihak lain yang mempunyai hubungan dengan perusahaan tersebut [5].

8. Jurnal Penutup

Jurnal penutup adalah jurnal yang dibuat pada akhir periode akuntansi dengan maksud untuk memindahkan saldo akun nominal atau akun sementara ke akun Modal (atau Laba Ditahan bagi perusahaan berbentuk perseroan terbatas), sehingga saldo akun Modal (Laba Ditahan) menunjukkan saldo akhir yang sesuai dengan apa yang tercantum dalam neraca akhir [8]. 
9. Jurnal Pembalik

Jurnal balik atau sering disebut jurnal penyesuaian kembali ke jurnal yang dibuat pada awal priode akuntansi untuk membalik jurnal penyesuaian tertentu. Jurnal balik ini tidak harus dibuat dalam satu siklus kegiatan akuntansi, jurnal balik dibuat pada awal periode akuntansi sebelum mulai melakukan transaksi dalam priode tersebut [5].

2.3 Unified Modelling Language (UML)

Adalah bahasa pemodelan khusus untuk sistem atau perangkat lunak dengan paradigma "beriorientasi objek". Pemodelan atau modeling sebenarnya digunakan khusus untuk menyederhanakan berbagai kendala yang kompleks sehingga nantinya mudah untuk dipelajari dan dipahami[11] [9].

\subsection{Blackbox testing}

Adalah tahap yang digunakan untuk menguji kelancaran program yang telah dibuat. Pengujian ini penting dilakukan agar tidak terjadi kesalahan alur program yang telah dibuat.

\section{Metode Penelitian}

Penelitian ini akan melalui beberapa proses, alur urutan proses pada penelitian ini adalah sebagai berikut :

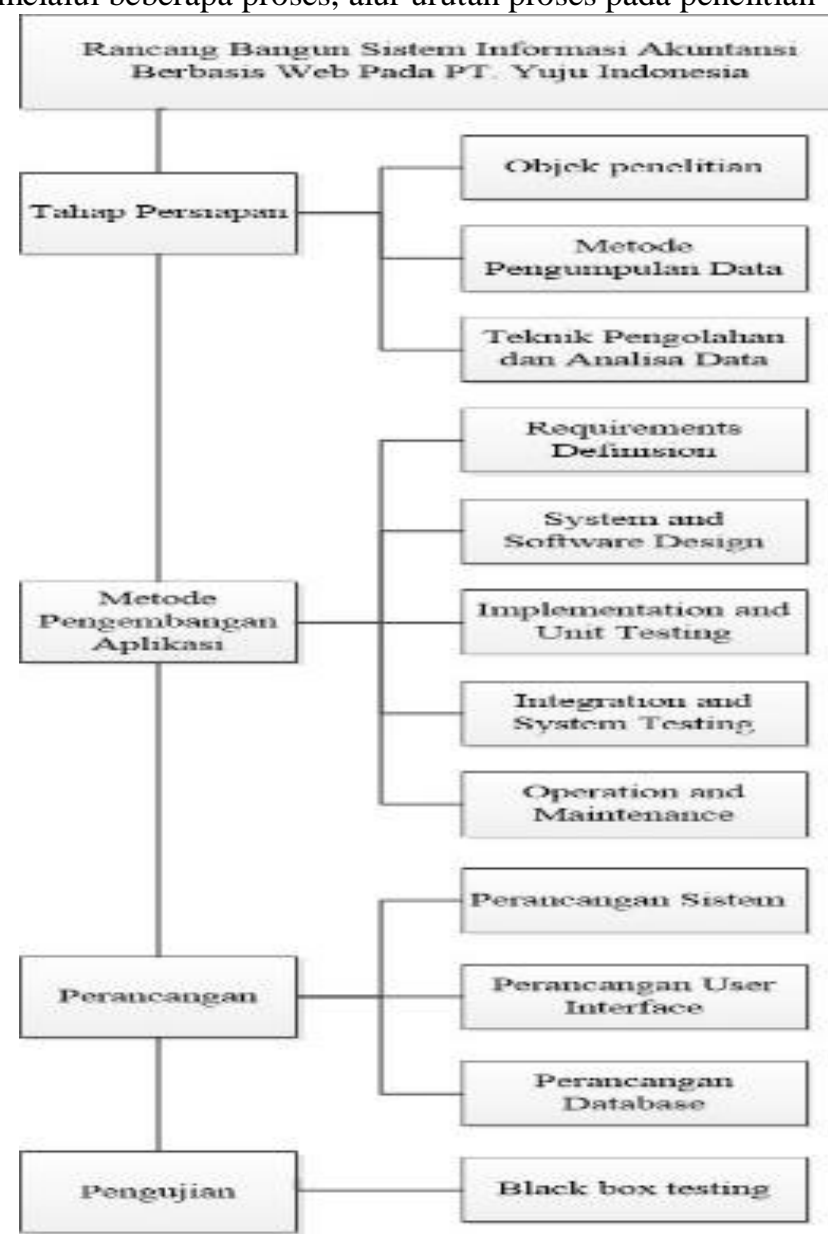

Gambar 2 Metode Penelitian

Tahapan awal dalam penelitian ini adalah dimulai dengan menentukan objek penelitian, metode pegumpulan data serta Teknik pengolahan data dan analisis data. Kemudian tahapan pada metode pengembangan aplikasi diawali oleh tahap analisis kebutuhan yang merupakan tahap awal pembangunan sebuah perangkat lunak. Tahap ini didefinisikan sebagai sebuah tahap yang menghasilkan sebuah kondisi yang diperlukan oleh pengguna untuk menyelesaikan permasalahan ataupun mencapai sebuah tujuan. Tahap ini bertujuan untuk megumpulkan kebutuhan-kebutuhan pengguna dan kemudian mentransformasikan ke dalam sebuah deskripsi yang jelas dan lengkap.

Tahapan kedua adalah tahap analisis sistem yang bertujuan untuk menjabarkan segala sesuatu yang nantinya akan ditangani oleh perangkat lunak. Tahapan ini adalah tahapan dimana permodelan merupakan sebuah representasi dari object di dunia nyata. Untuk memahami sifat perangkat lunak yang akan dibangun, 
analis harus memahami domain informasi, dan tingkah laku yang diperlukan.

Tahap ketiga adalah tahap perancangan perangkat lunak yang merupakan proses multi langkah dan berfokus pada beberapa atribut perangkat lunak yang berbeda yaitu struktur data, arsitektur perangkat lunak, dan detil algoritma. Proses ini menerjemahkan kebutuhan ke dalam sebuah model perangkat lunak yang dapat diperkirakan kualitasnya sebelum dimulainya tahap implementasi.

Tahap implementasi adalah tahap yang mengkonversi apa yang telah dirancang sebelumnya ke dalam sebuah bahasa yang dimengerti komputer. Kemudian komputer akan menjalankan fungsi-fungsi yang telah didefinisikan sehingga mampu memberikan layananlayanan kepada penggunanya.

Tahap selanjutnya adalah tahap pengujian yaitu metode black-box. Pengujian dengan metode black-box merupakan pengujian yang menekankan pada fungsionalitas dari sebuah perangkat lunak tanpa harus mengetahui bagaimana struktur di dalam perangkat lunak tersebut. Sebuah perangkat lunak yang diuji menggunakan metode black-box dikatakan berhasil jika fungsi-fungsi yang ada telah memenuhi spesifikasi kebutuhan yang telah dibuat sebelumnya.

Tahap akhir dari metode Waterfall adalah tahap perawatan. Tahap ini dapat diartikan sebagai tahap penggunaan perangkat lunak yang disertai dengan perawatan dan perbaikan. Perawatan dan perbaikan suatu perangkat lunak diperlukan, termasuk di dalamnya adalah pengembangan, karena dalam prakteknya ketika perangkat lunak tersebut digunakan terkadang masih terdapat kekurangan ataupun penambahan fitur-fitur baru yang dirasa perlu [10].

\section{Hasil dan Pembahasan}

Hasil dari penelitian ini adalah sebuah sistem informasi akuntansi berbasis web. Pada tahap ini penulis akan menjelaskan Alur Sistem Informasi, Use Case Diagram, Class Diagram dan hasil rancangan user interface aplikasi akuntansi yang telah dibuat.

4.1 Alur Sistem Informasi

Sesuai pembagian hak akses, aplikasi sistem informasi akuntansi berbasis web terbagi menjadi tiga user, yaitu: admin, staff accounting dan pemilik perusahaan (direktur). Dengan masing-masing tugas seperti dijelaskan pada gambar berikut:

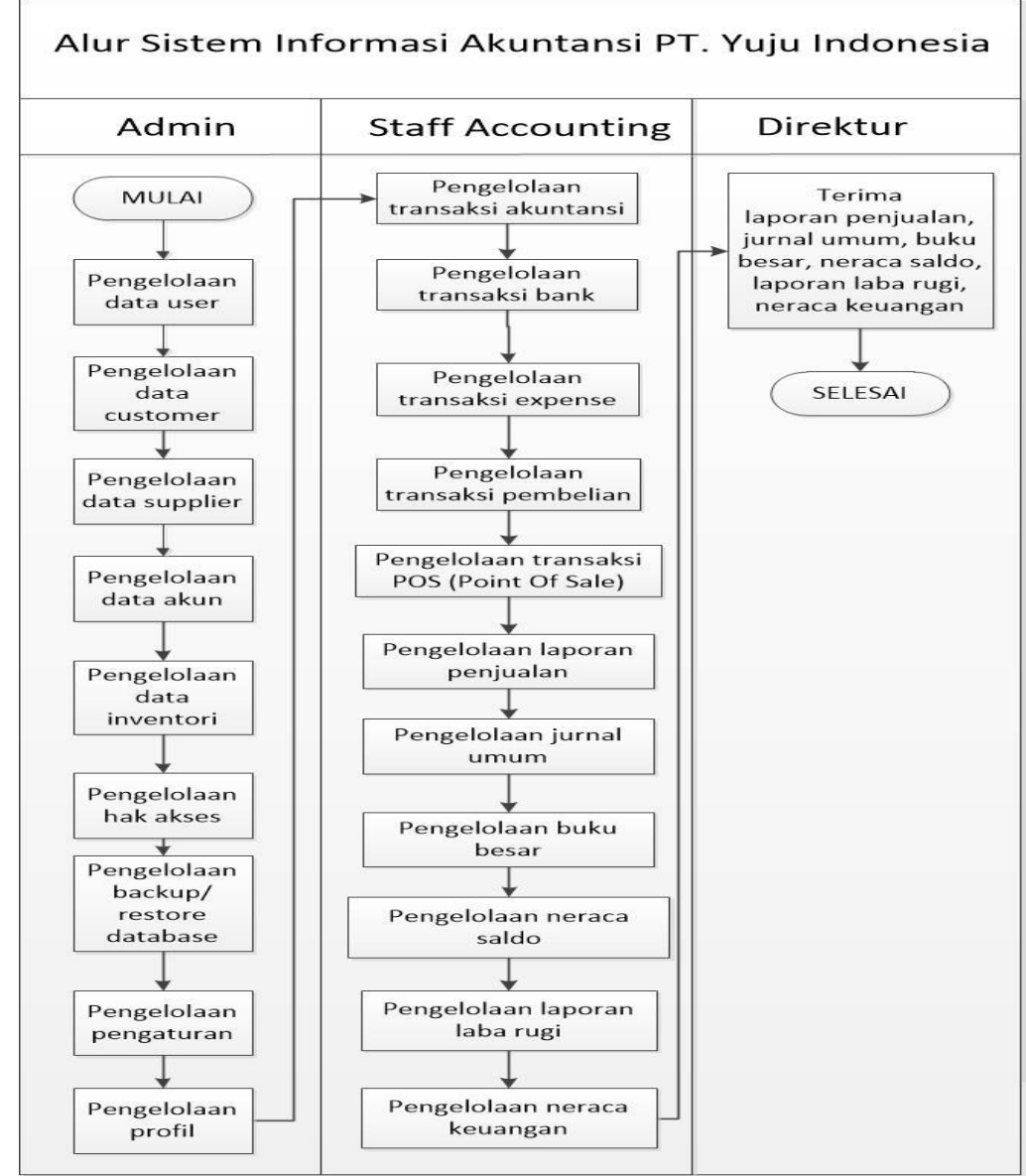

Gambar 3 Alur Sistem Informasi 


\subsection{Use Case Diagram}

Berdasarkan data-data yang diperoleh, maka dapat digambarkan mengenai analisa kebutuhan yang diperlukan dalam rancang bangun sistem informasi akuntansi, dalam hal ini pada PT. Yuju Indonesia ke dalam diagram Use case sebagai berikut :

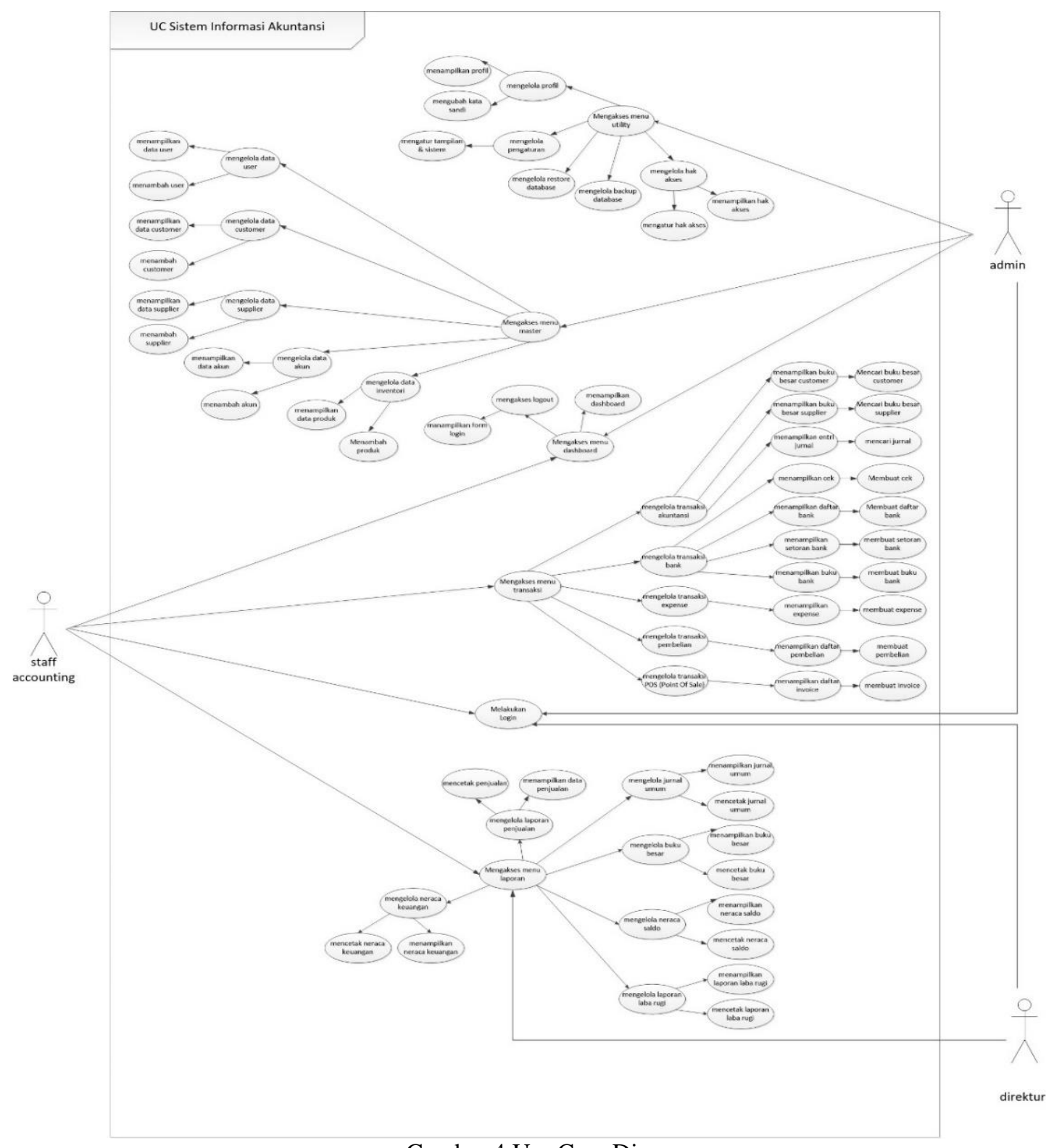

Gambar 4 Use Case Diagram

\subsection{Class Diagram}


Diagram kelas (class diagram) menunjukan interaksi antara kelas dalam sistem. Kelas mengandung informasi dan tingkah laku (behavior) yang berkaitan dengan informasi tersebut seperti yang di tunjukkan pada berikut:

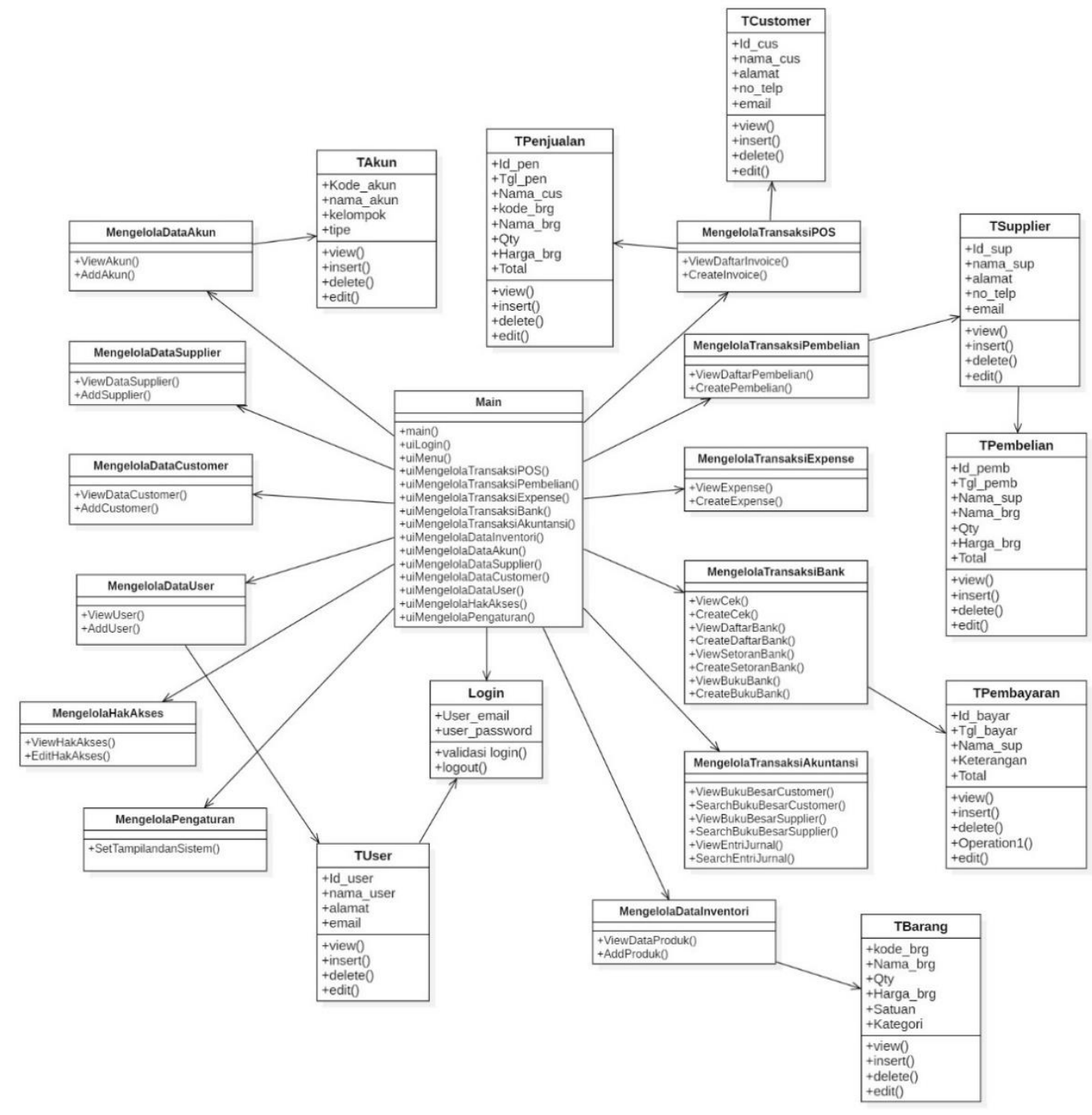

\subsection{User Interface}

Sistem Informasi Akuntansi yang akan diimplementasikan pada PT. Yuju Indonesia adalah berbasis website dengan 4 hak akses yaitu super admin, admin, staff accounting dan direktur. Implementasi user interface dari aplikasi akuntansi adalah sebagai berikut:

1. Halaman login

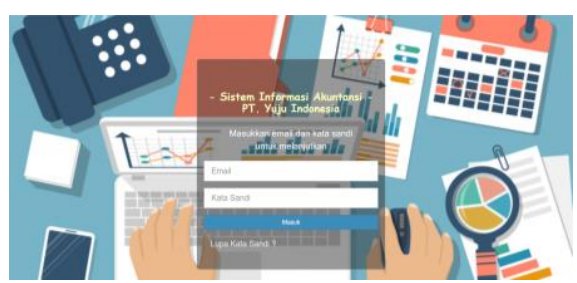

Gambar 3 Halaman Login

Halaman login merupakan tampilan pertama yang muncul pada saat program dijalankan, halaman login digunakan untuk mengatur jalannya sistem sesuai pembagian hak akses dengan email dan kata sandi sebagai pengamanan data transaksi.

2. Halaman Dashboard 


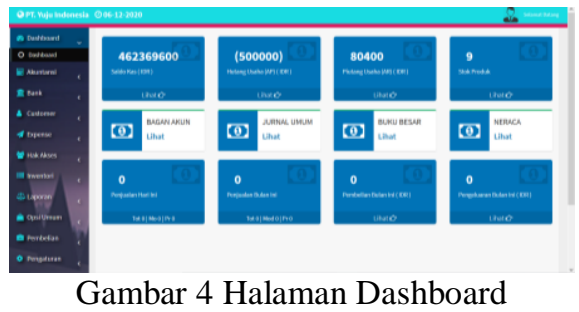

Pada halaman dashboard ditampilkan menu saldo kas, hutang usaha, piutang usaha, stok produk, penjualan hari ini, penjualan bulan ini, pembelian bulan ini dan menu pengeluaran bulan ini dan terletak 4 menu teratas yaitu: bagan akun, jurnal umum, buku besar dan neraca yang berguna untuk melihat secata cepat detail dari menu-menu tersebut.

\section{Halaman Buku Besar Customer}

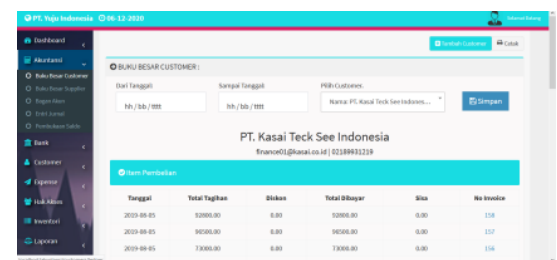

Gambar 5 Halaman Buku Besar Customer

Pada halaman buku besar customer, user dapat melihat transaksi-transaksi yang sebelumnya telah di input dimana buku besar menampilkan total tagihan dan total pembayaran oleh customer.

\section{Halaman Buku Besar Supplier}

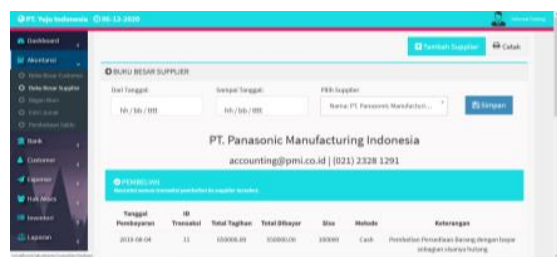

Gambar 6 Halaman Buku Besar Supplier

Halaman buku besar supplier berfungsi untuk melihat transaksi pembelian ke supplier yang sebelumnya telah di input dimana buku besar menampilkan total tagihan dan total yang dibayarkan.

5. Halaman Bagan Akun

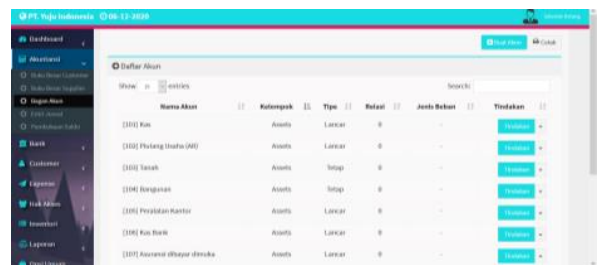

Gambar 7 Halaman Bagan Akun

Pada halaman bagan akun, user dapat melihat akun-akun yang sudah terdaftar dan dapat menambah, mengubah ataupun mengapus daftar akun.

6. Halaman Produk

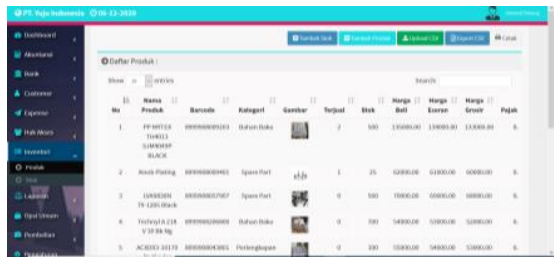

Gambar 8 Halaman Produk

Halaman produk menampilkan daftar produk yang terdiri dari nama produk, barcode, kategori, gambar, terjual, stok harga beli, harga eceran, harga grosir dan pajak. User dapat menambah stok, tambah 
produk maupun cetak.

7. Halaman Daftar Invoice

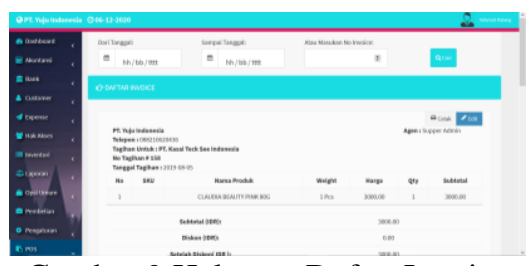

Gambar 9 Halaman Daftar Invoice

Halaman daftar invoice berisi tampilan invoice berdasarkan periode tertentu berdasarkan nama customer, no. invoice, tanggal, nama produk, weight, harga, quantity dan total.

8. Halaman Jurnal Umum

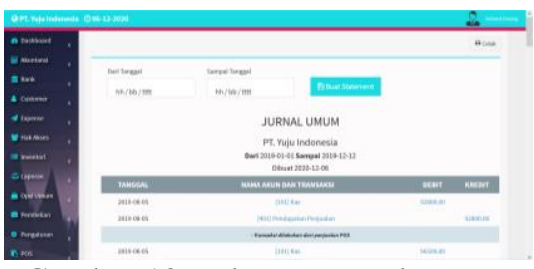

Gambar 10 Halaman Jurnal Umum

Halaman jurnal umum digunakan untuk mengelola jurnal umum tiap bulan dengan rincian tanggal, nama akun, uraian, kode akun, debit dan kredit. Pada akhir baris terakhir ditampilkan total debit dan kredit sehingga terlihat apakah total debit dan kredit sudah seimbang atau belum.

9. Halaman Buku Besar

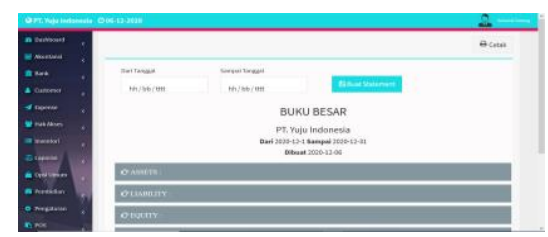

Gambar 11 Halaman Buku Besar

Halaman buku besar digunakan untuk menghitung saldo tiap kode akun dan bulan sesuai transaksi jurnal umum, jurnal penyesuaian, dan jurnal penutup. Button simpan digunakan untuk menyimpan saldo debit dan kredit terakhir setiap jurnal.

10. Halaman Neraca Saldo

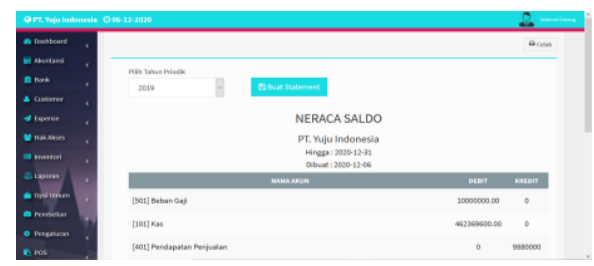

Gambar 12 Halaman Neraca Saldo

Halaman neraca saldo digunakan untuk menampilkan saldo terakhir tiap akun setelah adanya transaksi jurnal umum.

11. Halaman Laporan Laba Rugi

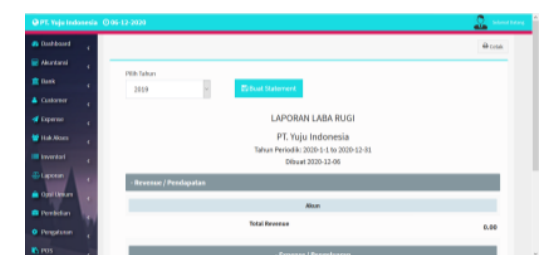

Gambar 13 Halaman Laporan Laba Rugi

Laporan laba rugi menampilkan jumlah setiap tabel pendapatan dan beban usaha sehingga dapat diketahui apakah dalam sebulan mengalami laba/rugi. 


\section{Halaman Neraca Keuangan (Balance Sheet)}

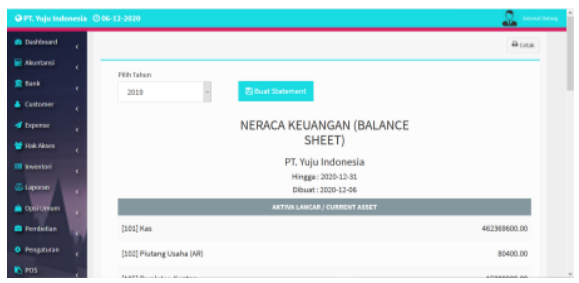

Gambar 14 Halaman Neraca Keuangan (Balance Sheet)

Laporan neraca berfungsi untuk menggambarkan keadaan perusahaan saat ini, termasuk didalamnya kekayaan, kewajiban dan modal yang dimiliki perusahaan.

4.5 Hasil Pengujian

Berdasarkan rencana pengujian yang telah dibuat menggunakan Black Box Testing, maka hasil pengujian perangkat lunak dari sistem informasi akuntansi adalah sebagai berikut:

\begin{tabular}{|c|c|c|c|}
\hline No. & Nama Pengujian & Proses Pengujian & Keterangan \\
\hline \multirow{3}{*}{1} & \multirow{3}{*}{ Menu Login } & $\begin{array}{l}\text { Menampilkan dan mengisi form email dan kata } \\
\text { sandi }\end{array}$ & Berhasil \\
\hline & & Menampilkan tombol masuk & Berhasil \\
\hline & & Menampilkan tombol lupa kata sandi & Berhasil \\
\hline \multirow[b]{2}{*}{2} & \multirow[b]{2}{*}{ Menu Dashboard } & Menampilkan halaman dashboard & Berhasil \\
\hline & & $\begin{array}{l}\text { Menampilkan menu saldo kas, hutang usaha, } \\
\text { piutang usaha, stok produk, penjualan hari ini, } \\
\text { penjualan bulan ini, pembelian bulan ini, } \\
\text { pengeluaran bulan ini }\end{array}$ & Berhasil \\
\hline \multirow{12}{*}{3} & \multirow{12}{*}{ Menu Akuntansi } & Menampilkan sub menu buku besar customer & Berhasil \\
\hline & & $\begin{array}{l}\text { Memilih periode serta nama customer untuk } \\
\text { ditampilkan data buku besar }\end{array}$ & Berhasil \\
\hline & & $\begin{array}{l}\text { Menampilkan tombol tambah customer dan } \\
\text { menu cetak }\end{array}$ & Berhasil \\
\hline & & Menampilkan sub menu buku besar supplier & Berhasil \\
\hline & & $\begin{array}{l}\text { Memilih periode serta nama supplier untuk } \\
\text { ditampilkan data buku besar }\end{array}$ & Berhasil \\
\hline & & $\begin{array}{l}\text { Menampilkan tombol tambah supplier dan menu } \\
\text { cetak }\end{array}$ & Berhasil \\
\hline & & Menampilkan halaman daftar akun & Berhasil \\
\hline & & Menampilkan tombol buat akun dan menu cetak & Berhasil \\
\hline & & Menampilkan halaman entri jurnal & Berhasil \\
\hline & & Membuat jurnal transaksi baru & Berhasil \\
\hline & & Menampilkan halaman saldo pembukaan & Berhasil \\
\hline & & Membuat saldo pembukaan baru & Berhasil \\
\hline \multirow{10}{*}{4} & \multirow{10}{*}{ Menu Bank } & Menampilkan sub menu cek & Berhasil \\
\hline & & $\begin{array}{l}\text { mencari data cek pada periode yang telah dibuat } \\
\text { sebelumnya }\end{array}$ & Berhasil \\
\hline & & Menampilkan tombol buat cek dan menu cetak & Berhasil \\
\hline & & Menampilkan halaman daftar bank & Berhasil \\
\hline & & $\begin{array}{l}\text { Menampilkan tombol tambah bank dan menu } \\
\text { cetak }\end{array}$ & Berhasil \\
\hline & & $\begin{array}{l}\text { Mencari data setoran bank pada periode yang } \\
\text { telah dibuat sebelumnya }\end{array}$ & Berhasil \\
\hline & & Membuat tombol buat setoran dan menu cetak & Berhasil \\
\hline & & Menampilkan halaman buku bank & Berhasil \\
\hline & & $\begin{array}{l}\text { Melihat buku bank pada periode tertentu yang } \\
\text { sudah dibuat sebelumnya }\end{array}$ & Berhasil \\
\hline & & Menampilkan tombol cetak & Berhasil \\
\hline
\end{tabular}




\begin{tabular}{|c|c|c|c|}
\hline No. & Nama Pengujian & Proses Pengujian & Keterangan \\
\hline \multirow{6}{*}{5} & \multirow{6}{*}{ Menu Customer } & Menampilkan sub menu customer & Berhasil \\
\hline & & Melihat tampilan daftar customer & Berhasil \\
\hline & & $\begin{array}{l}\text { Menampilkan tombol tambah customer, upload } \\
\text { csv, esport csv dan cetak }\end{array}$ & Berhasil \\
\hline & & Menampilkan halaman pembayaran customer & Berhasil \\
\hline & & $\begin{array}{l}\text { Mencari pembayaran customer berdasarkan } \\
\text { perode tertentu yang sudah dibuat sebelumnya }\end{array}$ & Berhasil \\
\hline & & $\begin{array}{l}\text { Menampilkan tombil buat pembayaran dan } \\
\text { cetak }\end{array}$ & Berhasil \\
\hline \multirow[b]{2}{*}{6} & \multirow[b]{2}{*}{ Menu Expense } & Melihat halaman expense & Berhasil \\
\hline & & $\begin{array}{l}\text { Mencari data expense pada peroide tertentu } \\
\text { yang sudah dibuat sebelumnya }\end{array}$ & Berhasil \\
\hline \multirow{5}{*}{7} & \multirow{5}{*}{ Menu Hak Akses } & Menampilkan sub menu atur hak akses & Berhasil \\
\hline & & Menampilkan daftar hak akses & Berhasil \\
\hline & & Menampilkan tombol tambah hak akses & Berhasil \\
\hline & & Menampilkan tombol search untuk hak akses & Berhasil \\
\hline & & Menampilkan tombol hapus hak akses & Berhasil \\
\hline \multirow{7}{*}{8} & \multirow{7}{*}{ Menu Inventori } & Menampilkan sub menu produk & Berhasil \\
\hline & & Menampilkan daftar produk & Berhasil \\
\hline & & Menampilkan tombol search untuk nama produk & Berhasil \\
\hline & & $\begin{array}{l}\text { Menampilkan tombol tambah stok, tambah } \\
\text { produkupload csv, export csv dan cetak }\end{array}$ & Berhasil \\
\hline & & Menampilkan halaman daftar ketersediaan stok & Berhasil \\
\hline & & Menampilkan tombol search untuk nama produk & Berhasil \\
\hline & & Menampilkan tombol cetak & Berhasil \\
\hline \multirow[b]{2}{*}{9} & \multirow[b]{2}{*}{ Menu Penjualan } & Melihat sub menu laporan penjualan & Berhasil \\
\hline & & $\begin{array}{l}\text { Menamplikan laporan penjualan berdasarkan } \\
\text { periode tertentu }\end{array}$ & Berhasil \\
\hline \multirow{8}{*}{10} & \multirow{8}{*}{ Menu Opsi Umum } & Menampilkan sub menu pengguna & Berhasil \\
\hline & & Menampilkan daftar pengguna & Berhasil \\
\hline & & $\begin{array}{l}\text { Menampilkan tombol search untuk nama } \\
\text { pengguna }\end{array}$ & Berhasil \\
\hline & & $\begin{array}{l}\text { Menampilkan tombol tambah pengguna dan } \\
\text { cetak }\end{array}$ & Berhasil \\
\hline & & Menampilkan menu backup database & Berhasil \\
\hline & & Menampilkan menu restore database & Berhasil \\
\hline & & Menampilkan menu pengaturan printer & Berhasil \\
\hline & & Menampilkan menu format data & Berhasil \\
\hline \multirow{3}{*}{11} & \multirow{3}{*}{ Menu Pembelian } & Menampilkan halaman daftar pembelian & Berhasil \\
\hline & & $\begin{array}{l}\text { Menampilkan tombol cari untuk menampilkan } \\
\text { pembelian pada periode tertentu }\end{array}$ & Berhasil \\
\hline & & $\begin{array}{l}\text { Menampilkan menu pembelian baru, retur } \\
\text { pembelian dan cetak }\end{array}$ & Berhasil \\
\hline \multirow{3}{*}{12} & \multirow{3}{*}{ Menu Pengaturan } & Menampilkan sub menu tampilan dan sistem & Berhasil \\
\hline & & Menampilkan pengaturan layout website & Berhasil \\
\hline & & Menampilkan tombol simpan & Berhasil \\
\hline \multirow{4}{*}{13} & \multirow{4}{*}{$\begin{array}{l}\text { Menu POS (Point } \\
\text { Of Sale) }\end{array}$} & Menampilkan sub menu daftar invoice & Berhasil \\
\hline & & Menampilkan invoice pada periode tertentu & Berhasil \\
\hline & & Menampilkan halaman buat invoice baru & Berhasil \\
\hline & & Menampilkan tombol simpan dan cetak & Berhasil \\
\hline \multirow{3}{*}{14} & \multirow{3}{*}{ Menu Profil } & Menampilkan halaman personal & Berhasil \\
\hline & & Menampilkan tombol ubah kata sandi & Berhasil \\
\hline & & Menampilkan informasi perusahaan & Berhasil \\
\hline 15 & Menu Statement & Menampilkan sub menu jurnal umum & Berhasil \\
\hline
\end{tabular}




\begin{tabular}{|c|c|c|c|}
\hline No. & Nama Pengujian & Proses Pengujian & Keterangan \\
\hline & & $\begin{array}{l}\text { Menampilkan halaman jurnal umum sesuai } \\
\text { periode tertentu }\end{array}$ & Berhasil \\
\hline & & Menampilkan menu cetak & Berhasil \\
\hline & & Menampilkan halaman neraca saldo & Berhasil \\
\hline & & Menampilkan menu cetak & Berhasil \\
\hline & & Menampilkan halaman laporan rugi laba & Berhasil \\
\hline & & Menampilkan menu cetak & Berhasil \\
\hline & & Menampilkan halaman neraca keuangan & Berhasil \\
\hline & & Menampilkan menu cetak & Berhasil \\
\hline \multirow{8}{*}{16} & \multirow{8}{*}{ Menu Supplier } & Menampilkan sub menu daftar supplier & Berhasil \\
\hline & & Menampilkan halaman daftar supplier & Berhasil \\
\hline & & $\begin{array}{l}\text { Menampilkan tombol search untuk mencari } \\
\text { nama supplier }\end{array}$ & Berhasil \\
\hline & & $\begin{array}{l}\text { Menampilkan tombol tambah supplier, upload } \\
\text { csv, export csv, cetak }\end{array}$ & Berhasil \\
\hline & & $\begin{array}{l}\text { Menampilkan tombol tindakan (lihat, hapus, } \\
\text { nonaktifkan) }\end{array}$ & Berhasil \\
\hline & & Menampilkan halaman pembayaran supllier & Berhasil \\
\hline & & $\begin{array}{l}\text { Mencari pembayaran supplier berdsarkan } \\
\text { periode tertentu }\end{array}$ & Berhasil \\
\hline & & Menampilkan tombol pembayarn baru dan cetak & Berhasil \\
\hline
\end{tabular}

\section{Kesimpulan}

Dari hasil penelitian yang telah dilakukan oleh peneliti , maka dapat diperoleh kesimpulan sebagai berikut:

1. Berdasarkan tahap analisa dan perancangan sistem informasi akuntansi yang dibangun menggunakan metode Unified Modelling Language (UML) dapat mengolah data keuangan dan akuntansi secara terkomputerisasi sehingga meminimalkan kesalahan, lebih mudah dan cepat jika dibandingkan dengan pengolahan data secara konvensional.

2. Sistem yang dibangun ini, menghasilkan output laporan penjualan dan pembelian, jurnal umum, buku besar, laporan laba rugi serta neraca saldo yang dapat ditampillkan berdasarkan periode tertentu.

\section{Daftar Pustaka}

[1] Krismiaji, Sistem Informasi Akuntansi, Yogyakarta: AMP YKPN, 2002.

[2] N. Hasanuh, Akuntansi Dasar: Teori dan Praktik, Jakarta: Mitra Wacana Media, 2011.

[3] S. Azhar, Sistem Informasi Akuntansi, Bandung: Lingga Jaya, 2013.

[4] D. Anastasia and L. Setiawati, Sistem Informasi Akuntansi Perancangan, Prosedur dan penerapan, Yogyakarta: Andi, 2011.

[5] R. Pura, Pengantar Akuntansi 1 Pendekatan Siklus Akuntansi, Jakarta: Penerbit Erlangga, 2013.

[6] Mulyadi, Sistem Akuntansi, Jakarta: Salemba Empat, 2008.

[7] Munawir, Analisis Laporan Keuangan, Yogyakarta: Penerbit Liberty, 2004.

[8] Rudianto, Pengantar akuntansi, Jakarta: Penerbit Erlangga, 2009.

[9] A. Nugroho, Rekayasa Perangkat Lunak Menggunakan UML \& Java, Yogyakarta: Andi Offset, 2010.

[10] B. K. Nugroho, Aplikasi Enkripsi SMS pada Telepon Selular berbasis J2ME dengan Metode Vigenere Cipher, Semarang: Universitas Diponegoro, 2010.

[11] M. F. Setiawan, M. N. Witama, and R. Hikmah, "Perancangan Sistem Pengolahan Data Produksi Konveksi Berbasis Java Pada CV Nirwana Bunga Abadi," J. Nas. Komputasi dan Teknol. Inf., vol. 3, no. 3, pp. 202-208, 2020. 